\title{
HMGA2/COX6C Fusion Gene
}

National Cancer Institute

\section{Source}

National Cancer Institute. HMGA2/COX6C Fusion Gene. NCI Thesaurus. Code C99430.

A fusion gene that results from a chromosomal translocation $\mathrm{t}(8 ; 12)$ which fuses the first three exons of the HMGA2 gene with exon 2 of the COX6C gene. This fusion is associated with uterine leiomyoma. 